\title{
A DUÁLIS KÉPZÉSBEN RÉSZT VEVŐ HALLGATÓK GYAKORLATI KOMPETENCIÁINAK MÉRÉSI ÉS ÉRTÉKELÉSI LEHETŐSÉGEI ${ }^{1}$
}

\author{
KOZÁK ANITA* - CSUGÁNY JULIANNA - TÁNCZOS TAMÁS \\ Eszterházy Károly Egyetem, Gazdaságtudományi Kar, Közgazdaságtan Tanszék
}

A versenyszféra által támasztott gyakorlatorientált felsőoktatás iránti igény hívta életre hazánkban is a duális formában zajló képzéseket. Jelen tanulmány célja a duális képzésben részt vevő hallgatók gyakorlati kompetenciáinak mérésére és értékelésére irányuló felmérés koncepcionális kereteinek felvázolása, mely az Eszzterházy Károly Egyetemen duális képzési formában is választható 12 szakon tanuló hallgatók körében kerül megvalósításra. A kompetenciamérést a felsőoktatási intézmény a gyakorlóhelyekkel együttműködve végzi el kérdőíves felmérés, értékelő központ és tereptanári értékelés alapján.

Kulcsszavak: duális képzés, gyakorlati kompetencia, kompetenciamérés, értékelés

The demand for practice-oriented higher education system by the private sector has led to the development of dual study programs in Hungary. The purpose of this study is to outline the conceptual framework for an examination on the measurement and assessment of practical competences of dual-level students. This examination will be used for students from 12 different dual study programs at Eszterhazy Karoly University. The competence assessment is carried out by the university in cooperation with the companies based on a questionnaire survey, assessment center and an assessment by the students' practical teacher at the company.

Keywords $¥$ dual study programs, practical competences, measure and value competences

Levelező szerző: Kozák Anita, Eszterházy Károly Egyetem Gazdaságtudományi Kar Közgazdaságtan Tanszék, 3300 Eger, Egészségház utca 4. E-mail: kozak.anita@uni-eszterhazy.hu

1 A tanulmányban bemutatott kompetenciamérési és -értékelési rendszer az „EFOP-3.5.1-16-2017-00011 Duális és gyakorlatorientált képzések fejlesztése az Eszterházy Károly Egyetemen” c. projekt céljaival összhangban készült. 


\section{Bevezetés}

$\mathrm{M}$ agyarországon 2015-ben került bevezetésre az Európa több országában már sikeresnek bizonyult duális felsőoktatási képzési forma illeszkedve azon munkaerőpiaci elváráshoz, mely a gyakorlati készségek hatékonyabb elsajátítását követeli meg a felsőoktatásban részt vevő hallgatóktól. A mindössze 4 éves múltra visszatekintő duális képzéssel kapcsolatban megállapítható, hogy a képzési formát választó hallgatók száma dinamikusan nő, melyhez illeszkedve egyre több intézmény, egyre több szakon kínálja ebben a formában is a képzéseit. A legnépszerübbek továbbra is a mérnöki és a gazdaságtudományi képzések, s megfigyelhető az is, hogy a vidéki felsőoktatási intézményekben e képzési formában tanulók száma magasabb a fővárosi intézményekben tanulókhoz képest. Jelenleg mintegy kétezer hallgató vesz részt duális képzésben, a vállalati partnerszervezetek száma pedig már meghaladja a hétszázat (EMMI 2019).

Magyarországon hosszú évekre visszanyúlóan végeznek kompetenciaméréseket a közoktatásban, a felsőoktatásban azonban nincs erre irányuló egységes gyakorlat. A felsőfokú képzések gyakorlatorientáltságának növelése iránti munkapiaci igény indokolttá teszi olyan felmérések készítését, melyek a gyakorlati kompetenciák elsajátításának eredményességét hivatottak mérni. A képzések eredményességének nyomon követése érdekében az Eszterházy Károly Egyetemen kidolgoztunk egy olyan mérésértékelési rendszert, mely alkalmas a gyakorlatorientáltságot a legmagasabb szinten biztosító duális képzésekben az elsajátítható általános és szakmai kompetenciák felmérésére, fejlődésük figyelemmel kísérésére és a hagyományos képzési formákkal történő összehasonlításra is. Jelen tanulmány célja e kompetenciamérési gyakorlat koncepcionális kereteinek felvázolása, melynek három alappillére a hallgatói kérdőíves felmérés, az értékelő központ és tereptanári értékelés.

\section{A duális képzés alapelve és magyarországi helyzete}

A felsőoktatási intézmények és a gazdaság hatékony együttműködésének egyik alapfeltétele, hogy az egyetemek és főiskolák a munkaerőpiaci igényeknek megfelelő szakembereket képezzenek. E cél megvalósítása csak a gazdasági szereplőkkel való szoros kapcsolattartással és a piaci és társadalmi elvárásokhoz igazodó képzésekkel érhető el. A duális képzés lényegét annak indulásakor a Duális Képzési Tanács a következőképpen fogalmazta meg: "A duális képzés tehát a gyakorlatigényes alapképzési szakon folytatott képzés azon formája, amelyben a szakmailag minösitett vállalatoknál folyó gyakorlati képzések tantervi tartalmuknál, struktúrájuknál és a vállalatoknál töltendö, megnövelt óraszámuknál, valamint a megszerzett munkatapasztalatnál fogva növelik a hallgatók szakmai kompetenciáját, vállalati ismereteit és erösítik a kultúráját."

A képzés lényege a párhuzamosság, azaz a felsőoktatási intézményben elsajátított elméleti ismeretanyagot a hallgató vállalati, szervezeti keretek között mélyíti el és ülteti át a gyakorlatba.

A német mintájú duális képzést Magyarországon először a Kecskeméti Főiskolán (ma Neumann János Egyetem) indították el két jelentős autóipari cég közremüködésével járműmérnöki szakon, 2012-ben. A „kecskeméti modell” kedvező tapasztalatai rá- 
irányították a figyelmet a duális képzési forma szükségességére, mely 2014-ben bekerült a felsőoktatási törvénybe, ${ }^{2}$ s a 2014/2015-ös tanévtől kezdődően a felsőoktatási intézmények már indíthatnak duális képzési formában szakokat. Ekkor nevesítették a duális képzések központi szakmai felügyeleti szervét, a Duális Képzési Tanácsot is. A felsőoktatási információs portál (felvi.hu) adatai szerint a tanulmányaikat a 2019/2020-as tanévben megkezdők már 68 duális alap- és mesterképzési szak közül választhatnak. ${ }^{3}$

Az Állami Számvevőszék 2018-ban kérdőíves felmérés keretében gyüjtött információkat a duális képzésekről a felsőoktatási intézményektől annak érdekében, hogy az elmúlt évek fejlődési irányait elemezzék. Az ÁSZ jelentéséből kiderül, hogy a kezdeti tapasztalatok kedvezőek, az új képzési forma népszerűségét jelzi, hogy 2015-ről 2017-re csaknem megháromszorozódott a duális képzésben részt vevő hallgatók száma az állami fenntartású felsőoktatási intézményekben, ugyanakkor megállapították azt is, hogy érdemi átalakulást még nem sikerült a gyakorlatorientáltságra törekvő felsőoktatásban ezzel az új képzési modellel elérni (Németb-Renkó-Beke 2018). Célként kezdetben megfogalmazódott, hogy duális képzésbe az érintett szakterületeken a hallgatók 6\%-át kellene bevonni (Derényi 2016). Később a Kormány a „Fokozatváltás a felsőoktatásban" középtávú szakpolitikai stratégiában azt a célt tűzte ki, hogy a duális alapképzésben részt vevő hallgatók aránya a releváns képzési területeken, az elsőévesek körében 2020-ra elérje a 8\%-ot. A felsőoktatásban a hallgatók száma az elmúlt években csökkenő tendenciát mutat, ugyanakkor a duális képzési formát választók száma nő, így arányuk javul. Ennek ellenére a duális hallgatók száma 2017-ben is csak megközelíti az $1 \%$-át $(0,81 \%)$ a nappali tagozatos képzésben tanulóknak. ${ }^{4} \mathrm{Ha}$ a négy leginkább érintett szakterületet (műszaki, gazdaságtudományi, informatika, agrár) nézzük, akkor a duális képzés hallgatóinak létszámaránya 2015-ben 0,6\%,2016-ban 1,2\%,2017ben $1,8 \%$ volt (Németh-Renkó-Beke 2018).

\section{A kompetencia értelmezése és a kompetenciamérés}

A kompetencia meghatározására számos definíció született. Spencer és Spencer (1993) szerint a kompetencia az egyénnek az a megkülönböztető tulajdonsága, amely oksági kapcsolatban áll egy kritériumhoz kötött hatékony és/vagy jobb teljesítményhez a munkakör betöltése kapcsán. Boyatzis (1982) is hasonlóan írja le a fogalmat, szerinte a kompetencia az egyén hatékony és/vagy kiváló munkaköri teljesítményét eredményező személyiségjellemzője. Karcsics (2011) értelmezésében a kompetencia a képességet, készséget, tudást és a teljesítményre való alkalmasságot egyszerre leíró fogalom. Karoliny és Poór (2013) részletesebb megfogalmazásában a kompetencia a munkát végző ember tudásának, munkavégző képességének kifejezője, a körülhatárolt tapasztalatok, értékek és összekapcsolt információk heterogén és folyton változó keveréke; szakértelem, amely keretet ad új tapasztalatok, információk elbírálásához és elsajátításához, s a tudással rendelkezők elméjében hasznosul. A kiragadott definíciókból egyértelmúen érezhetö, hogy a kompetencia közgazdasági megközelítésben leginkább a munkavégzéshez kapcsolódó fogalom, azokat a képességeket, készségeket és tulajdonságokat fog-

\footnotetext{
2011. évi CCIV, törvény a nemzeti felsőoktatásról; beiktatta: 2014. évi XXXVI. törvény 40. $§(1)$.

Részletesen lásd https://www.felvi.hu/felveteli/dualisdiploma/partnerszervezetek.

2015-ben 0,26\%, 2016-ban 0,53\% volt a duális hallgatók aránya.
} 
lalja magában, amelyek alkalmassá teszik az egyént egy adott foglalkozás magas szintű müvelésére.

A kompetenciáknak többféle csoportosítása ismert, a legegyszerübb és leggyakrabban alkalmazott felosztás szerint vannak általános és szakmaspecifikus kompetenciák. Az előbbi szakterülettől függetlenül járul hozzá az eredményes munkavégzéshez (pl. együttmüködési készség), az utóbbi egy-egy adott szakmához köthető (pl. munka- és egészségvédelmi ismeretek, szakmai ismeretek). Egy másik csoportosítás szerint (Mohácsi 2003) léteznek személyes (pl. motiváció) és szociális kompetenciák (pl. konfliktuskezelés). Ezek mellett a kompetenciák hard és soft felosztása is ismert (Jacobs 1989), melyek között a legnagyobb különbség a mérhetőségükben van, míg a hard kompetenciák a jól mérhető, objektív, feladatorientált technikai kompetenciák (pl. matematikai kompetencia), addig a soft kompetenciák nehezen mérhetők, szubjektívek és érzelmi alapúak (pl. befolyásoló képesség). Az Európai Közösségek Bizottsága az egész életen át tartó tanulást szolgáló Európai Képesítési Keretrendszer (EKKR) kialakításánál a kompetencia alábbi négy elemét különböztette meg (EKB 2005):

- kognitív kompetencia, amely kiterjed az elmélet és a fogalmak, valamint a tapasztalati úton szerzett, informális passzív tudás alkalmazására;

- funkcionális kompetencia (készségek vagy know-how), amelyre egy konkrét (munkahelyi, tanulási vagy társadalmi) tevékenység gyakorlásához van szükség;

- személyes kompetencia, amely magába foglalja annak ismeretét, hogyan viselkedjünk egy bizonyos helyzetben;

- etikai kompetencia, amely a függetlenség és felelősség kifejlesztése során lényeges személyes és szakmai értékeket foglal magában.

A felsőoktatásban ezzel összhangban a szakok képzési és kimeneti követelményeiben $(\mathrm{KKK})$ az alábbi négy kompetenciaelemet különböztetik meg: tudás, képesség, attitűd, valamint autonómia és felelősség. E megkülönböztetés a képzési és kimeneti követelményekben illeszkedve a Magyar Képesítési Keretrendszer (MKKR) szintleírásaihoz a kompetencia belső összetevőjének tekinti a tudást, a képességeket és az attitüdöket, melyekhez a tevékenység során kapcsolódik az autonómia és a felelősségvállalás (Derényi-Vámos 2015).

A kompetenciák mérésére számos módszert fejlesztettek ki, ezek közül a legismertebbek és leggyakrabban alkalmazottak az alábbiak (Varga 2014; Hegyi 2012; Vojtek et al. 2013):

- megfigyelés: a dolgozó munkavégzés közbeni megfigyelése - általában meghatározott szempontrendszer alapján történik az értékelés;

- kritikus helyzetek vizsgálata: az interjú olyan speciális formája, amelyben az adott munkakörben meghatározó jelentőségűnek tekintett eseményre adott reakciókra, viselkedéses válaszokra és attitüdök feltérképezésére törekszenek (pl. munkagép hirtelen meghibásodása vagy egy munkahelyi konfliktus kezelése) - a módszerrel előre jelezhető a hasonló jövőbeli helyzetekben tanúsított magatartás;

- viselkedésinterjú: a kritikus helyezetek vizsgálatának egy továbbfejlesztett változata, a lényegi különbség a viselkedésinterjú „emberibb” vonatkozásában érhető tetten, ugyanis inkább érzésekre, gondolatokra, motivációkra és szándékokra kérdez rá; 
- KOZÁK ANITA - CSUGÁNY JULIANNA - TÁNCZOS TAMÁS: A DUÁLIS KÉPZÉSBEN RÉSZT VEVŐ...

- repertoárteszt: az eljárás során a munkavállaló összehasonlításokat végez - általában, nem kizárólagosan - önmaga és két másik munkatársa kompetenciái között úgy, hogy ő maga határozza meg, melyik az a dimenzió (kompetencia, konstrukció), amelyre az összehasonlítást alapozza - a módszer nagy előnye, hogy a munkát végző személyek maguk határozzák meg a kompetenciákat;

- kérdöíves vizsgálatok: tesztkérdésekkel, leíró jelleggel vagy értékelőskálás módszerrel a munkát végző maga (adott esetben a közvetlen felettese is) értékeli a dolgozót az általában munkaköri leírás alapján - előre meghatározott kompetenciák mentén;

- értékelö(-fejlesztö) központ: életszerü helyzeteken keresztül, a kompetenciákat felszínre hozva, általában 3-5 fös csoportokban, meghatározott szempontrendszer alapján figyelik meg és értékelik a munkavállalókat (adott esetben fejlesztést célzó javaslatokkal is ellátják őket);

- Q-válogatás: az előre maghatározott kompetenciákból választja ki a munkavállaló a rá jellemzőket és/vagy a munkakör betöltéséhez legfontosabbnak ítélteket, azokat jelentőségük szerint rangsorolja, majd ezeket vethetjük össze a munkakör betöltéséhez elöírt kompetenciákkal.

\section{A kompetenciamérési és -értékelési rendszer}

A duális képzésben részt vevő hallgatók gyakorlati kompetenciáinak méréséhez és értékeléséhez használandó rendszer kidolgozását a duális formában indított képzések szakfelelősei és szakoktatói, valamint az egyetemmel duális együttmüködési megállapodást kötött vállalkozások szakemberei segítették. A folyamat a duális képzésekhez kapcsolódó kompetenciatérképek elkészítésével indult és az eredmények visszacsatolásával, felhasználásával zárul (1. ábra).

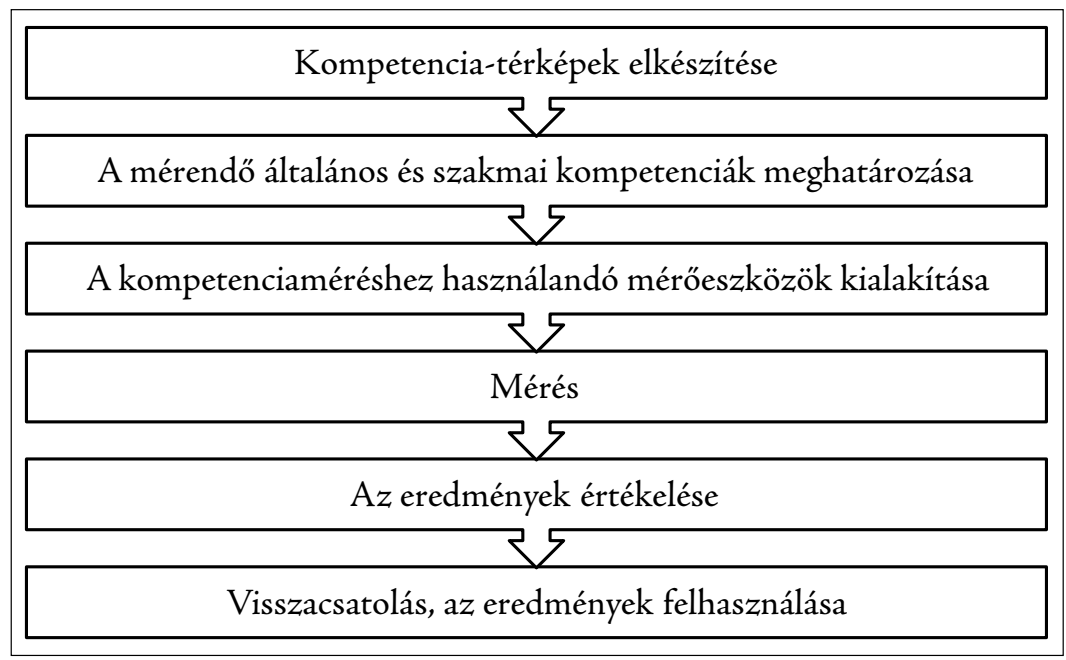

1. ábra: A kompetenciamérési és -értékelési rendszer kidolgozásának folyamatábrája Forrás: saját szerkesztés (2019) 
Első lépésben a duális képzések szakfelelősei és szakoktatói elkészítették a kompetencia-térképeket, ${ }^{5}$ amelyekhez több forrásból gyüjtöttek információkat. Figyelembe vették a szakhoz kapcsolódó képzési és kimeneti követelményekben leírtakat, a szak elvégzésével betölthető jellemző munkakörök FEOR szerinti leírását és a foglalkozásjellemzőket, valamint a vállalati partnerek duális hallgatókkal foglalkozó szakembereinek elvárásait. Utóbbihoz kapcsolódóan félig strukturált interjús vizsgálatokat végeztek a vállalati mentorokkal/tereptanárokkal. Az elkészült kompetencia-térképek két csoportra, általános és szakmai kompetenciákra osztják a munkavégzéshez kapcsolódó gyakorlati kompetenciákat. Az általános kompetenciák szaktól függetlenek, míg a szakmai kompetenciák a szakterület-specifikus ismeretek alapján kerültek meghatározásra. A kompetencia-térképek szakonként 12-16 általános és szakmai kompetenciát, azok összekapcsolódását, a kompetenciák leírását és elvárt szintjét tartalmazzák.

A kompetencia-térképek elkészülését követően összesítettük a kapott adatokat és kiválasztottuk a 10 legfontosabbnak értékelt általános kompetenciát. A mérendő, legjelentősebbnek vélt 10 szakmai kompetenciát az adott szak felelőse - egyeztetve a vállalati partnerek szakembereivel - választotta ki. Ezek jellemzően a tudás és képesség kompetenciaelemhez kapcsolódnak, míg az általános kompetenciák inkább a személyes jellemzőket helyezik elötérbe.

$\mathrm{A} z$ általános kompetenciák mérése egységes minden duális képzési formában tanuló hallgató esetében, míg a szakmai kompetenciákhoz szakonként eltérő mérőeszköz került kialakításra. Annak érdekében, hogy komplex képet kapjunk a duális képzésben részt vevő hallgatók kompetenciáiról, három módszer segítségével, a lehető legtöbb résztvevő bevonásával mérjük azokat. $\mathrm{A} z$ általános kompetenciák értékelése tesztkérdéses kérdőívvel, valamint értékelő központos vizsgálattal történik, a szakmai kompetenciákat szintén tesztkérdéses kérdőívvel, valamint a hallgató vállalati mentora/tereptanára által kitöltött értékelőskálás módszerrel mérjük. E három módszer kombinációja alkalmas arra, hogy komplex képet adjon a duális képzésben részt vevő hallgatók gyakorlati kompetenciáiról (2.ábra).

\begin{tabular}{|c|c|c|}
\hline $\begin{array}{c}\text { Kérdőív } \\
\text { (tesztkérdések) }\end{array}$ & Értékelő központ & $\begin{array}{c}\text { Kérdőív } \\
\text { (értékelőskálák) }\end{array}$ \\
\hline $\begin{array}{l}\text { + Képes az általános és } \\
\text { szakmai kompetenciák } \\
\text { mérésére is. } \\
\text { + Online felületen történik a } \\
\text { felmérés. } \\
\text { + A hallgató önállóan végzi. }\end{array}$ & $\begin{array}{l}\text { + Az általános kompeten- } \\
\text { ciákat méri. } \\
\text { + Tantermi keretek között } \\
\text { zajlik a vizsgálat. } \\
\text { + A kompetenciamérést és } \\
\text {-értékelést kompetens } \\
\text { egyetemi oktatók végzik. }\end{array}$ & $\begin{array}{l}\text { + A szakmai kompetenciákat } \\
\text { méri. } \\
\text { + Online felületen történik az } \\
\text { értékelés. } \\
\text { + A hallgató vállalati } \\
\text { mentora/tereptanára } \\
\text { végzi. }\end{array}$ \\
\hline
\end{tabular}

2. ábra: A kompetenciaméréshez alkalmazott módszerek

Forrás: saját szerkesztés (2019)

\footnotetext{
5 A munkakörök ellátásához szükséges kompetenciákat és azok elvárt szintjét a kompetencia-térképek foglalják magukba. Ezek egyik eleme a szakmai és kapcsolódó általános ismereteknek, képességeknek és készségeknek köre, amelyek a feladatok ellátásának nélkülözhetetlen feltételét jelentik (Varga 2014).
} 
Az általános és szakmai kompetenciák objektív mérésére tesztkérdéses kérdőivet állítottunk össze. A mérni kívánt kompetenciákhoz négy, fokozatosan nehezedő kérdés tartozik. Az értékelés 1-től 4-ig terjedő skálán történik úgy, hogy a legkönnyebben megválaszolható kérdés 1, a legnehezebbnek tekinthető pedig 4 pontot ér. Egy kompetenciához így $1+2+3+4$, azaz összesen 10 pont tartozik. A kérdések összeállításánál arra törekedtünk, hogy azok egyértelműen értelmezhetők és megválaszolhatók legyenek, $\mathrm{s}$ valóban mérjék az adott kompetenciaelemet. Utóbbi érdekében a gyakorlati élethez kötődő szituációs feladatokat fogalmaztunk meg. A kérdések összeállításánál jelöltük azt a kompetenciaelemet, melyet az adott kérdés mérni kíván. Az általános kompetenciáknál elsősorban az attitűdre és a képességekre, valamint néhány esetben az autonómia és felelősség részre került a hangsúly, a szakmai kompetenciáknál viszont az ismeret dominált, és annak alkalmazási képessége volt a fontos.

A tesztkérdéseket a program vegyesen válogatja össze egyrészt a kompetenciák, másrészt azon belül az eltérő súlyúak tekintetében. Ezzel elkerülhető a mechanikus gondolkodás, és reális képet kaphatunk a hallgatók valós kompetenciakészletéről. A tesztkérdések összeállításánál összesen 10 általános és 10 szakmai kompetencia került kiválasztása, azaz külön-külön 100 pontos rendszerben értékelhetők a kompetenciák összesen 80 kérdés alapján.

$A z$ értékelö központos vizsgálaton két, a kompetenciamérésért és -értékelésért felelős egyetemi oktató és egy pszichológus végzettségü szakember van jelen. A hallgatók értékelését a két oktató végzi, a pszichológus az esetlegesen felmerülő nehéz helyzetek kezelése, a hallgatók lehetséges szorongásának feloldása miatt tagja a bizottságnak. Az értékelő központos vizsgálat zavartalan lebonyolítására az egyetem egyik kisebb tantermében kerül sor. A termet előzetesen berendezzük a vizsgálathoz és biztosítjuk a szükséges tárgyi és technikai eszközöket. Egyszerre három (maximum öt) hallgató vesz részt a vizsgálaton. A bizottság bemutatkozását követően ismertetjük a hallgatókkal a vizsgálat célját, majd rátérünk a feladatokra. Minden feladat egyszerre két kompetenciát mér, így összesen öt feladatot tartalmaz az értékelő központos vizsgálat. A tesztkérdéses kérdőívhez hasonlóan itt is 10 pont tartozik egy-egy kompetenciához. A két értékelő egymástól függetlenül értékel, 10-10 pontot adhatnak kompetenciánként, az általuk adott pontértékek egyszerü számtani átlaga adja a hallgató értékelését.

Az értékelő skálás minősités a szakmai kompetenciák felmérésére szolgál, az értékelést a hallgató szakmai gyakorlóhelyén lévő mentor/tereptanár végzi. A kérdőívben a kompetenciákhoz 2-2 kérdést rendeltünk, így összesen 20 itemet tartalmaz a mérőeszköz. A két kérdésre egyenként maximálisan 5 pontot kaphat a hallgató, így kompetenciánként 10 pontot szerezhet. E kérdések meghatározásánál is figyelembe vettük a viselkedésalapúság elvét, tehát a kompetenciák viselkedésben való megnyilvánulására helyeztük a hangsúlyt.

A kompetenciamérés eredményeinek értékelése és felhasználása tekintetében elmondható, hogy a kompetenciák értékelése kompetenciánként történik, azaz az általános kompetenciák tekintetében a 4-4 tesztkérdés és az értékelö központos vizsgálat, a szakmai kompetenciáknál a 4-4 kérdés és az értékelőskálás kérdőív eredményei alapján minden kompetenciához tartozik két pontérték egy tízfokozatú skálán. Ez lehetőséget teremt arra, hogy minden hallgató esetében elkészüljön egy empirikus kompetencia-térkép, amelyen láthatóvá válik, hogy az egyes kompetenciáknál milyen vizsgálat keretében milyen eredményeket ért el, mely területeken erősebb, és hol vannak 
a gyengébb értékek. Ez utóbbi területekre a szakfelelősök által kompetenciafejlesztési tervek is megfogalmazhatók a képzés további részére vonatkozóan.

A kompetenciákra kapott pontértékek összegezhetők is, ezáltal a hallgatók összevont teljesítménye is értékelhető és összehasonlítható. A hallgatók eredményeinek öszszevont értékelése alapján az adott szakra vonatkozóan is megállapítható, hogy mely kompetenciaterületeken mutatkoznak hiányosságok, melyeket a továbbiakban fejleszteni szükséges, s mely területek erősek. Ezek a tapasztalatok beépíthetők az elméleti és a gyakorlati képzésbe, szükségessé tehetik a tantervek megváltoztatását, a tananyagtartalmak aktualizálását. A kompetenciák mérése tanévenként, mindig október vagy november hónapban történik, a teszt eredményét a szakfelelősök egyenként vitatják meg a hallgatókkal és jelölik ki azokat a területeket, amelyek fejlesztése szükséges a hallgató részéről. A kompetenciamérési és értékelési rendszer alkalmas arra is, hogy a hagyományos és a duális képzési formák - a kompetenciák fejlettsége tekintetében - összehasonlíthatók legyenek. Jövőbeli terveink között szerepel egy ilyen összehasonlító vizsgálat, előzetesen ugyanis azt feltételezzük, hogy a duális képzési formát választó hallgatók gyakorlati kompetenciái jobbak, szakmai tapasztalataik alapján könnyebben képesek alkalmazkodni az aktuális munkapiaci elvárásokhoz. A hárompilléres mérési rendszer emellett lehetővé teszi a hallgatók egyéni fejlődési pályájának nyomon követését is, valamint hozzájárul a versenyszféra elvárásaihoz igazodó képzési tartalmak kialakításához a felsőoktatásban.

\section{Összegzés}

Magyarországon a versenyszféra által támasztott gyakorlatorientált felsőoktatás iránti igény hívta életre a duális formában zajló képzéseket, melyek megteremtik a lehetőségét annak, hogy a felsőoktatási intézményekben elsajátítható elméleti ismeretekkel párhuzamosan azt a gyakorlati tudást is megszerezzék a hallgatók, melynek birtokában már pályakezdőként is szakmai gyakorlattal rendelkező munkavállalóként léphetnek a munkaerőpiacra. E képzési forma számos kiaknázatlan lehetőséget rejt magában, mely javíthatja a felsőoktatási rendszerből kikerülő hallgatók munkaerőpiaci sikerességét, valamint gyakorlatorientáltabb képzési programok kidolgozására ösztönzi a felsőoktatási intézményeket.

$\mathrm{A} z$ Eszterházy Károly Egyetemen kidolgozásra került egy hárompilléres kompetenciamérés-értékelési rendszer, mely a duális képzésben részt vevő hallgatók gyakorlati kompetenciáinak mérésére irányul. A modell kidolgozása során szem előtt tartottuk a képzési és kimeneti követelményekben megfogalmazott kompetenciaelvárásokat, valamint a felsőoktatási intézmények és a duális partnerszervezetek együttmüködésén alapuló rendszer kidolgozására törekedtünk. Az általános és szakmai kompetenciákat kérdőív, értékelő központos vizsgálat, valamint értékelő skálás kérdőív segítségével mérjük, melyek lehetővé teszik az egyes kompetenciák szakok szerinti, illetve időbeli összehasonlító vizsgálatát is. A többpilléres módszer egyrészt megkülönböztethetővé teszi a hallgatók és a szakok szintjén is az általános és szakmai kompetenciákat, valamint lehetővé teszi a hagyományos és duális képzési formában tanulók kompetenciakészletének összehasonlíthatóságát is. E két tulajdonsága megalapozza a munkaerőpiaci elvárásokhoz alkalmazkodó képzési programok kidolgozását és a megfelelő kompetenciákkal rendelkező hallgatók kibocsátását a munkapiacra. 
KOZÁK ANITA - CSUGÁNY JULIANNA - TÁNCZOS TAMÁS: A DUÁLIS KÉPZÉSBEN RÉSZT VEVŐ...

\section{IRODALOM}

2011. évi CCIV. törvény a nemzeti felsőoktatásról.

Boyatzis, R. E. (1982) The Competent Manager: A Modell for Effective Performance. Boston, John Wiley \& Sons.

Derény A. (2016) Kézikönyv a duális képzésröl. Budapest, Tempus Közalapítvány.

Derényi A. \& VÁmos Á. (2015) A felsőoktatás képzési területeinek kimeneti leírása-ajánlások. Egy kisérleti fejlesztés eredménye. Budapest, Oktatási Hivatal.

Duális Képzési Tanács: A duális felsőfokú képzés alapelvei. http://www.kormany.hu/ download/4/1d/50000/Az\%20Nftv-ben\%20meghatározott\%20képzési\%20terület\%20 alapképzési\%20szakán\%2C\%20illetve\%20mesterképzési\%20szakán\%20duális\%20formában\%20folytatott\%20képzések\%20általános\%20szakmai\%20és\%20minősítési\%20 követe.pdf\#!DocumentBrowse [Letöltve: 2019. 02. 20.]

EMMI (2019) Európai Uniós Fejlesztéspolitikáért Felelős Államtitkárság. http://www. kormany.hu/hu/emberi-eroforrasok-miniszteriuma/europai-unios-fejlesztespolitikaertfelelos-allamtitkarsag/hirek/felsooktatasi-fejlesztesek-dualis-kepzes [Letöltve: 2019. 03. 08.]

EKB (2005) Európai Közösségek Bizottsága: Javaslat az egész életen át tartó tanulást szolgáló Európai Képesitési Keretrendszer kialakitására. https://www.oktatas.hu/pub_bin/dload/ LLL/ekkr/orszagos_konzultacio2005/ekkr_sec_2005_957_fin.pdf [Letöltve: 2019. 03. 08.]

Felvi.hu: $A$ duális képzés. https://www.felvi.hu/felveteli/jelentkezes/felveteli_tajekoztato/ FFT_2019K/6_kepzesi_sajatossagok/61_dualis_kepzes [Letöltve: 2019.02.20.]

Felvi.hu: Duális diploma - partnerszervezetek listája. https://www.felvi.hu/felveteli/ dualisdiploma/partnerszervezetek [Letöltve: 2019. 02. 20.]

Fokozatváltás a felsőoktatásban - középtávú szakpolitikai stratégia 2016. http://www.kormany. $\mathrm{hu} /$ download/c/9c/e0000/Fokozatvaltas_Felsooktatasban_HONLAPRA.PDF [Letöltve: 2019.03 .08 .]

Hegri H. (2012) Személy(iség) a kompetenciák mögött - A hagyományos pszichológiai kiválasztási eljárások és a kompetenciák mérésének összefüggései ( $\mathrm{PhD}$-értekezés). Pécsi Tudományegyetem, Alkalmazott Pszichológiai Doktori Program.

Jacobs, R. (1989) Getting the Measure of Managerial Competence. Personnel Management, Vol. 21. No. 6. pp. 32-37.

Karcsics É. (2011) Menedzseri kompetencia-elvárások a munkaeröpiacon (PhD-értekezés). Budapesti Műszaki- és Gazdaságtudományi Egyetem, Gazdálkodás- és Szervezéstudományi Doktori Iskola.

Karoliny M. \& Poór J. (2013) Emberi eröforrás menedzsment kézikönyv. Budapest, Complex Kiadó Kft.

Mohácsi G. (2003) Kompetencia és érzelmi intelligencia. In: Karoliny M., Farkas F, Poór J. \& LÁszló Gy. (eds) Emberi eröforrás menedzsment kézikönyv. Budapest, KJKKERSZÖV Jogi és Üzleti Kiadó. pp. 415-443.

Németr E., Renkó Zs. \& Beke A. (2018) A magántőke bevonásának hatásai a felsőoktatási képzési rendszerre. A duális képzési rendszer tapasztalatai. Budapest, Állami Számvevőszék. https://asz.hu/storage/files/files/Publikaciok/Elemzesek_tanulmanyok/2018/ magantoke_bevonasa_felsooktatas.pdf?ctid=1237 [Letöltve: 2019. 02. 20.]

Oktatási Hivatal: Felsőoktatási statisztikák. https://www.oktatas.hu/felsooktatas/ kozerdeku_adatok/felsooktatasi_adatok_kozzetetele/felsooktatasi_statisztikak [Letöltve: 2019.02 .24 .] 
Spencer, L. M. \& Spencer, S. M. JR. (1993) Competence at Work: Models for Superior Performance. Boston, Wiley.

VARGA E. (2014) A személyes kompetenciák átértékelödése az emberi eröforrás menedzsment és a gazdasági felsőoktatás szemszögéböl (PhD-értekezés). Gödöllő, Szent István Egyetem, Gazdálkodás és Szervezéstudományok Doktori Iskola.

Vojtek É., Juhász G., Erdős M. \& Garai P. (2013) A kompetenciák szerepe és jelentősége a munkaerőpiaci esélyek fokozásában, valamint a munkakörelemzésben és értékelésben. Szakképzési Szemle, Vol. 29. No. 1. pp. 5-20.

A cikk a Creative Commons Attribution 4.0 International License (https://creativecommons.org/licenses/ by/4.0/) feltételei szerint publikált Open Access közlemény, melynek szellemében a cikk bármilyen médiumban szabadon felhasználható, megosztható és újraközölhető, feltéve, hogy az eredeti szerző és a közlés helye, illetve a CC License linkje és az esetlegesen végrehajtott módosítások feltüntetésre kerülnek. (SID_1) 